\title{
STUDI REVITALISASI KAWASAN PENGRAJIN KERAMIK YANG BERWAWASAN LINGKUNGAN PERILAKU GUNA MENCARI KONSEP PERANCANGAN ARSITEKTUR DI KELURAHAN DINOYO, KOTA MALANG
}

\author{
Adhi Widyarthara \\ Dosen Prodi Arsitektur, Fak. Teknik Sipil dan Perencanaan, ITN Malang \\ e-mail: adhiwidyarthara@lecturer.itn.ac.id \\ Didiek Suharjanto \\ Dosen Prodi Arsitektur, Fak. Teknik Sipil dan Perencanaan, ITN Malang \\ e-mail: suharjantodidiek@gmail.com
}

\begin{abstract}
ABSTRAK
Pada tahun 1958, masyarakat Dinoyo mulai merintis membuat keramik; hal tersebut berlanjut hingga kini dengan berbagai produk keramik seperti vas bunga, souvenir, guci, serta lampu set. Seiring perjalanan waktu, pada tahun 2000-an pasar keramik mencapai titik jenuh dan mengalami penurunan pasar. Diantara penyebab penurunan aktivitas kawasan pengrajin Dinoyo diakibatkan oleh keterbatasan infrastruktur yang ada ditempat produksi maupun pedagang keramik sehingga menjadikan ketidaknyamanan para pengrajin dan pengunjung dalam memenuhi kebutuhannya. Untuk meningkatkan vitalitas kawasan agar terbentuk suasana yang nyaman dalam berinteraksi antara pengrajin maupun pengunjung serta layak untuk dikunjungi sebagai kawasan wisata, maka dibutuhkan suatu proses identifikasi perencanaan dan perancangan lingkungan sesuai perilaku pengrajin maupun masyarakat dalam pengelolaan serta pemanfaatan aset properti pada kawasan keramik guna memperbaiki, mengembangkan atau melestarikan bangunan dan lingkungan yang berwawasan lingkungan perilaku. Peran Pemerintah perlu mengupayakan program-program pembangunan yang menekankan penggunaan bahan lokal yakni bahan yang tidak membahayakan kesehatan dan lingkungan, rancangan yang hemat energi serta penggunaan teknologi padat karya yang mempekerjakan lebih banyak orang
\end{abstract}

Kata kunci : identifikasi kawasan, revitalisasi, kenyamanan wisata.

\begin{abstract}
In 1958, the people of Dinoyo began pioneering making ceramics; this continues until now with various ceramic products such as flower vases, souvenirs, jars, and set lights. Over time, in the 2000s the ceramic market reached a saturation point and experienced a decline in the market. Among the causes of the decline in the activity of the Dinoyo craftsmen area was due to the limited infrastructure available at the production sites as well as the ceramic traders, which made the craftsmen and visitors inconvenient in fulfilling their needs. To increase the vitality of the area in order to create a comfortable atmosphere in interaction between craftsmen and visitors and
\end{abstract}

PAWON: Jurnal Arsitektur, Nomor 01 Volume 3, Bulan Januari-Juni Tahun 2019, ISSN 2597-7636 
worth visiting as a tourist area, a process of identification of environmental planning and design is needed according to the behavior of craftsmen and the community in managing and utilizing property assets in ceramic areas to improve, develop or preserve environmentally sound buildings and environments. The role of the Government needs to seek development programs that emphasize the use of local materials, namely materials that do not endanger health and the environment, energy-efficient designs and the use of labor-intensive technologies that employ more people.

Keywords : area identification, revitalization, tourist convenience.

\section{PENDAHULUAN}

Sejarah kegiatan masyarakat Dinoyo, memiliki keterampilan dalam memproduksi benda-benda keramik diawali dengan berdirinya Pabrik Keramik milik Departemen Perindustrian dengan nama Perusahaan Daerah Keramika Yasa pada tahun 1957. Setahun kemudian, masyarakat Dinoyo mulai merintis membuat keramik berupa peralatan makan dan minum. Jumlah pengrajin mencapai puncaknya yakni pada tahun 1998 dengan total 210 pengrajin se Wilayah Malang Raya; kemudian menurun hingga dibawah 50 pengrajin. Data dari Paguyuban Keramik pada tahun 2016, terdapat 31 anggota dengan rincian 15 anggota memiliki aktivitas usaha bidang keramik, 9 anggota beraktivitas di bidang gips serta 7 anggota yang melakukan usaha lain bukan pada bidang keramik maupun gips.

Keberadaan tata ruang yang kurang nyaman, sehingga dapat menyebabkan pengunjung kurang tertarik untuk mendatangi ruang pamer produk kerajinan keramik. Keterbatasan aksesibilitas menuju kawasan pengrajin keramik, menjadikan tujuan menjadikan Kampung Wisata Keramik memerlukan konsep perancangan arsitektur yang sesuai agar kenyamanan pengunjung dapat menjadi daya tarik pengunjung untuk mendatangi kawasan pengrajin keramik Dinoyo.

Guna melestarikan kawasan pengrajin keramik Dinoyo yang rencana pengembangannya tercantum dalam Peraturan Daerah Kota Malang nomor 7 Tahun 2001 tentang peningkatan obyek wisata sebagai pusat souvenir di Malang Raya; membutuhkan suatu upaya merevitalisasi kawasan yang dapat meningkatkan vitalitas kawasan sehingga terjadi kenyamanan dalam berinteraksi antara pengrajin maupun pengunjung serta layak dikunjungi sebagai destinasi wisata yakni Kampung Wisata Keramik Dinoyo.

Undang-undang nomor 11 Tahun 2011 tentang Cagar Budaya menyebutkan tentang kawasan yang perlu dilestarikan karena memiliki nilai penting bagi sejarah, ilmu pengetahuan, pendidikan dan atau kebudayaan. Hal ini dapat diberlakukan pada kawasan Keramik Dinoyo, karena benda cagar budaya buatan manusia yang memiliki hubungan erat dengan

PAWON: Jurnal Arsitektur, Nomor 01 Volume 3, Bulan Januari-Juni Tahun 2019, ISSN 2597-7636 
kebudayaan masyarakat dan sejarah perkembangan manusia setempat serta memiliki usia lebih dari 50 tahun, maupun kelangkaannya terdapat pada kawasan ini. Keberadaan undang-undang ini dipergunakan sebagai dasar untuk melakukan upaya merevitalisasi kawasan, dengan mengumpulkan data, melakukan analisa tentang aktivitas pengrajin dan pengunjungnya (Adhi,2016) pengkajian makna kultural (Sidharta,1989), merumuskan kebijakan, sesuai Peraturan Menteri Pekerjaan Umum nomor 06 Tahun 2007 tentang pola penataan perbaikan kawasan agar revitalisasi kawasan dapat dilakukan.

\section{TINJAUAN PUSTAKA}

Terjadinya penurunan kualitas fisik, dapat diketahui dengan melakukan pengamatan aktivitas melalui beberapa tahapan untuk memahami behavior setting (Joyce,2004) para pemilik, pekerja serta pengunjung pada kawasan Pengrajin Keramik di RW 03 Kelurahan Dinoyo Kota Malang; diantaranya adalah melakukan pengamatan dalam mengurai aktivitas kesehariannya dalam kinerja mereka, demikian juga mengetahui pola interaksi dalam lingkungan, mengamati atau melakukan identifikasi saat awal hingga akhir kegiatan dengan maksud untuk mendapatkan karakter pola aktivitasnya yang spesifik guna menentukan konsep rancangan revitalisasi kawasan pengrajin keramik. Persepsi kenyamanan lingkungan juga dipengaruhi oleh kesesakan dan kepadatan (Stokols,1972); mengingat kendala keruangan yang terjadi pada saat kesesakan merupakan respon subjektif terhadap ruang yang sesak, sedangkan kepadatan merupakan indikator karena timbulnya persepsi kesesakan.

Revitalisasi adalah upaya untuk merubah fungsi suatu tempat guna meningkatkan nilai lahan/kawasan melalui pembangunan fasilitas dalam suatu kawasan yang dapat meningkatkan fungsi kawasan sebelumnya (Sidharta,1989). Untuk menyelesaikan permasalahan psikologis manusia terhadap tempat beraktivitas karena aspek-aspek lingkungannya, dibutuhkan kajian lingkungan mikro, lingkungan meso maupun lingkungan makro (Stokols,1977). Lingkungan mikro meliputi ruangan dimana mereka melakukan aktivitas dan berinteraksi, lingkungan meso meliputi rumah dan lingkungannya, sedangkan lingkungan makro meliputi kawasan beraktivitas dikaitkan dengan aktivitas kota (Hariyadi,2010).

Proses melakukan aktualisasi personal, membutuhkan fasilitas yang spesifik tergantung persepsi dan aktivitasnya serta dianggap merupakan wilayah yang sudah menjadi milik seseorang. Klasifikasi ruang personal dikaitkan dengan tuntutan kebutuhan dan dianggap menjadi miliknya disebut suatu teritori, yang didasarkan pada derajat privasi, afiliasi dan kemungkinan pencapaian (Altman,1980) terdiri dari teritori primer, teritori sekunder dan teritori publik. Teritori primer merupakan tempat-tempat yang sangat pribadi

PAWON: Jurnal Arsitektur, Nomor 01 Volume 3, Bulan Januari-Juni Tahun 2019, ISSN 2597-7636 
sifatnya dan hanya boleh dimasuki oleh orang-orang yang sudah sangat akrab atau yang sudah mendapat izin khusus, teritori ini dimiliki oleh perseorangan atau sekelompok orang yang juga mengendalikan penggunaan teritori tersebut secara relatip tetap berkenaan dengan kehidupan sehari-hari. Teritori sekunder merupakan tempat-tempat yang dimiliki bersama oleh sejumlah orang yang sudah cukup saling mengenal. Teritori publik merupakan tempat-tempat yang terbuka untuk umum.

\section{METODE PENELITIAN}

Proses melakukan revitalisasi merupakan pilihan untuk menyelesaikan permasalahan serta menjaga daya hidup suatu kawasan pengrajin keramik di Dinoyo berdasarkan kemampuan untuk hidup, tumbuh dan berkembang, dengan meningkatkan kualitas fasilitas kawasan serta melestarikan bangunan yang dulu berperanan dalam memperkuat keberadaan kawasan sehingga memiliki peranan sejarah dalam membentuk suatu citra kawasan sebagai penghasil keramik di Kota Malang.

Metode penelitian yang dipergunakan adalah metode kualitatif, sehingga dalam melakukan penelitian berdasarkan latar belakang permasalahan serta alasan yang menguatkan agar penelitian dilakukan. Sehingga keberadaan kajian kepustakaan yang menghasilkan kesesuaian paradigma, rumusan masalah, kesesuaian paradigma dengan teori substansi dalam mendapatkan keterangan sangatlah dibutuhkan. Selain itu, diperlukan pula tentang pemilihan lapangan untuk penelitian ataupun setting penelitian, pemilihan alat penelitian, rancangan pengumpulan data maupun rancangan analisis data untuk mencapai tujuan yang telah ditetapkan.

Pada tahapan mengenali lingkungan tempat beraktivitas para pekerja baik berupa ruang pamer maupun tempat produksi, membutuhkan banyak waktu untuk wawancara dengan pekerja maupun dengan pemilik tempat kerja guna mendapatkan informasi tentang bagaimana beraktivitas, tuntutan kebutuhan ruangnya, permasalahan yang dirasakan saat melakukan aktivitas, kemudian membuat sketsa ruang untuk memahami tata ruang maupun efektivitas mereka dalam beraktivitas. Tahapan berikutnya adalah mengkaitkan tempat mereka bekerja dengan lingkungannya, melakukan pengamatan antar tempat kerja dengan wawancara dengan masing-masing pemilik ruang pamer maupun tempat produksi, wawancara dengan pengunjung, pengamatan lingkungan tentang fasilitas yang disediakan oleh kawasan guna menambah kenyamanan pengunjung dalam melakukan aktivitas belanja maupun rekreasi. Pada akhirnya, mengamati keberadaan fasilitas penanda kawasan, beberapa fasilitas yang keberadaannya dapat membuat interaksi yang harmonis antara fasilitas kota maupun kawasan. 
Proses merumuskan hipotesa atau pendapat sementara, berdasarkan data yang didapatkan sebelumnya akan memiliki makna dalam menyelesaikan berbagai permasalahan yang terjadi dan meningkatkan potensi sebagai sesuatu yang positif guna meningkatkan perkembangan fungsi suatu kawasan agar berkelanjutan.

\section{HASIL DAN PEMBAHASAN}

Revitalisasi merupakan suatu keputusan tindak lanjut dari proses konservasi pada lingkungan bersejarah, yakni kawasan yang tetap memegang teguh tradisi budaya setempat lebih dari 50 tahun; namun mengalami penurunan kualitas fisik yakni penurunan produktivitas ekonomi, degradasi lingkungan dan kerusakan warisan budaya. Pada tahun 2013, data yang diperoleh dari kawasan pengrajin keramik menunjukkan; terdapat 20 unit usaha keramik, 13 unit usaha gips, serta 2 unit usaha keramik diluar paguyuban. Tahun 2016, terdapat 15 unit usaha keramik, 9 unit usaha gips serta 2 unit usaha keramik yang baru, kegiatan produktivitas ekonomi tersebut jauh menurun dibandingkan dengan pada saat booming ditahun 1998 yang tercatat 210 pengrajin. Penurunan produktivitas tersebut, disebabkan banyak faktor dan beberapa diantaranya adalah aksesibilitas menuju kawasan yang relatif sulit serta terbatasnya fasilitas yang disediakan untuk pengunjung oleh pengrajin maupun kawasan.

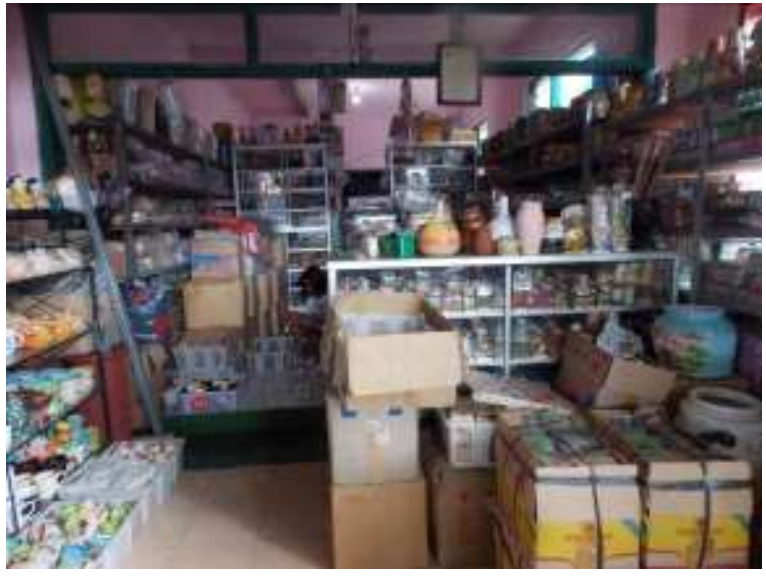

Gambar. 1

Suasana ruang pamer

Sumber: koleksi pribadi

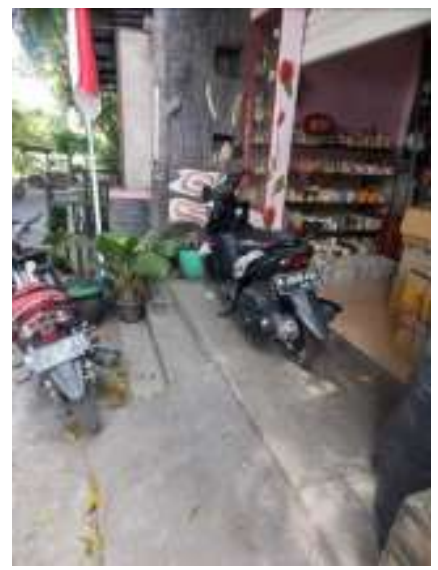

Gambar. 2

Ruang Transisi

Sumber: koleksi pribadi

Guna meningkatkan kemandirian para pengrajin di kawasan Dinoyo agar dapat tumbuh dan berkembang, dibutuhkan suatu upaya perbaikan maupun penambahan fasilitas infrastruktur yang berjenjang, mulai dari lingkungan mikro, lingkungan meso hingga lingkungan makro. Lingkungan

PAWON: Jurnal Arsitektur, Nomor 01 Volume 3, Bulan Januari-Juni Tahun 2019, ISSN 2597-7636 
mikro, berada pada tempat tinggal para pengrajin; yang perlu ditingkatkan adalah keberadaan fasilitas tempat kerja yang berupa ruang pamer ataupun tempat produksi keramik serta fasilitas ruang transisi yang merupakan ruang penghubung antara teritori publik dengan teritori primer. Masalah yang terjadi pada ruang pamer maupun tempat produksi secara umum adalah kurang baiknya tatanan benda yang dijual atau perabot sehingga menyebabkan sirkulasi pengunjung ataupun pekerja menjadi terganggu; penyelesaiannya dapat dilakukan dengan menambah ruang baru sebagai penunjang ruang pamer atau tempat produksi. Sedangkan keberadaan ruang transisi bagi ruang pamer maupun tempat produksi dibutuhkan sebagai ruang peralihan agar kondisi psikologis pengunjung mudah menyesuaikan dengan tuntutan suasana ruang yang akan dikunjungi. Lingkungan meso, meliputi hubungan antar ruang pamer maupun tempat produksi dengan lingkungannya. Selama ini, yang terjadi di kawasan pengrajin keramik Dinoyo tidak didapatkan fasilitas penghubung baik berupa trotoar maupun ruang terbuka hijau; oleh karenanya, upaya pemenuhan fasilitas itu perlu dan secara bertahap harus diwujudkan, ada dua manfaat yang akan didapatkan dengan pemenuhan tersebut, pertama adalah kenyamanan pengunjung akan didapatkan dan keduanya adalah lingkungan menjadi lebih sehat. Terakhir adalah lingkungan makro, yakni terjadinya proses sinergi antara fasilitas kawasan dengan fasilitas kota. Beberapa potensi aset properti kawasan yang dapat dikembangkan agar pengunjung terfasilitasi dengan baik dan akhirnya mereka akan merasa nyaman dan kerasan dalam melakukan kunjungan ke kawasan pengrajin yang sekaligus berwisata.

Kawasan pengrajin keramik di Dinoyo, merupakan perintis usaha keramik di Malang; hal tersebut memiliki ketergantungan terhadap keberadaan Pabrik Keramik yang sekarang sudah tidak berproduksi lagi karena produknya kurang kompetitif dalam persaingan dengan produk perusahaan lain yang sejenis. Keberadaan Pabrik Keramik tersebut, ternyata memiliki sumberdaya manusia yang cukup handal dalam mengelola produksi keramik. Keandalan sumberdaya manusianya dalam berkreasi pada akhirnya ditularkan kepada masyarakat disekitar Pabrik Keramik, sehingga memunculkan aneka jenis produk dengan desain yang menarik dan diakui oleh dunia. Hal lain yang dapat diadopsi oleh masyarakat dalam proses produksi adalah penggunaan teknologi tungku pembakaran, begitu teknologi yang digunakan harus berubah maka masyarakat pengrajin keramik perlu menyesuaikan dan saat ini produknya masih kalah bersaing dengan produk sejenis dengan material beda, misalnya plastik.

Kecenderungan pembongkaran dan penggusuran bangunan kuno yang bersejarah dan sebagai pembentuk budaya masyarakat setempat pada keterampilan pembuatan keramik. Memunculkan motivasi mempertahankan warisan budaya dan warisan sejarah, perlu ditumbuh 
kembangkan karena dalam lingkungan pengrajin keramik telah didapatkan karakteristik tentang tata nilai sosial, nilai ilmiah serta nilai komersial yang membentuk jati diri penghuni yang berdomisili. Menjadikan masyarakat mandiri secara ekonomis dengan bermatapencaharian pengrajin keramik yang memiliki keterampilan spesifik membutuhkan waktu yang lama dan sudah merupakan budaya sehingga tidak dapat dihilangkan begitu saja. Budaya yang didapatkan adalah menjadikan mereka yang memiliki keterampilan mumpuni ditempatkan pada strata sosial tertinggi. Oleh karenanya, pemilik tempat produksi selalu menyediakan waktu dan tempat untuk melatih mereka yang ingin belajar membuat benda keramik sekaligus mengembangkan ilmu pengetahuan tentang keramik. Sebagai hasil kreatifitas produk mereka kemudian dipamerkan dan sekaligus dijual kepada masyarakat. Prestasi pengrajin keramik Dinoyo ini juga membanggakan karena produknya juga sering diikutsertakan pada event pameran internasional yakni Negara-negara Asia Timur, Eropa, Timur Tengah dan Australia.

Keberadaan Undang-Undang Cagar Budaya nomor 11 tahun 2011, merupakan upaya berikutnya dalam mempertahankan warisan sejarah dengan adanya benda cagar budaya yang berupa bekas Pabrik Keramik Dinoyo. Diharapkan apabila pelestarian aset properti bangunan bekas Pabrik Keramik dapat disetujui, maka proses revitalisasi kawasan pengrajin keramik akan lebih cepat; mengingat keberadaan Pabrik Keramik tersebut merupakan landmark kawasan sekaligus merupakan area inti kegiatan pada kawasan pengrajin keramik, juga didalamnya terdapat aset lahan yang dapat difungsikan sebagai penunjang bagian area inti yakni tempat parkir pengunjung yang saat ini fasilitas tersebut sangat terbatas. Meningkatkan vitalitas kawasan yang lain adalah menyediakan fasilitas jalan bagi pengunjung yang berupa teritori agar pengguna jalan tidak mengganggu keberadaannya, sedangkan peningkatan kualitas lingkungan kawasan dilakukan dengan pembukaan ruang transisi akibat pembebasan lahan dengan difungsikannya garis sempadan bangunan dan difungsikan sebagai jalur hijau, yang dahulunya berfungsi sebagai ruang pada lahan yang sama. Deliniasi kawasan dilakukan dengan memberikan informasi kepada masyarakat tentang kegiatan proses produksi pada ruang transisi, hal tersebut diharapkan juga menambah citra kawasan sebagai kawasan pengrajin keramik karena saat ini hanya satu pengrajin yang menggunakan ruang transisi untuk kegiatan proses produksi keramik.

Berdasarkan rekam jejak tersebut, menguatkan proses revitalisasi yakni melakukan perubahan agar dapat meningkatkan fungsi kawasan keramik Dinoyo. Hal tersebut perlu dilakukan karena potensi yang ada sangat membanggakan; terlebih lagi dikuatkan dengan adanya Peraturan Daerah Kota Malang nomor 7 Tahun 2001 tentang peningkatan obyek

PAWON: Jurnal Arsitektur, Nomor 01 Volume 3, Bulan Januari-Juni Tahun 2019, ISSN 2597-7636 
wisata yang menyebutkan kawasan keramik Dinoyo sebagai pusat produksi souvenir Kota Malang.

Ada 3 hal yang perlu untuk dipertimbangkan guna pelestarian bangunan dan lingkungan pada kawasan pengrajin keramik Dinoyo, hal tersebut adalah pemenuhan nilai sosial, yakni keberadaan bangunan atau lingkungan yang menjadi pusat kegiatan keramik; pemenuhan nilai ilmiah, yakni keberadaan bangunan atau lingkungan yang memiliki manfaat terhadap pengembangan ilmu maupun jasa informasi; pemenuhan nilai komersial, yakni keberadaan bangunan atau lingkungan yang memiliki arti penting guna melakukan kegiatan yang menghasilkan uang. Pemenuhan nilai sosial, keberadaan kawasan pengrajin keramik di Dinoyo berawal dari terpilinnya lokasi ini oleh Lembaga Penyelenggara Perusahaan-Perusahaan Industri yakni Perusahaan Daerah Keramika Yasa sebagai produsen peralatan makan dan minum seperti piring, cangkir, moci, basi dan peralatan lainnya; saat ini proses sosial masyarakat dalam pemenuhan kebutuhan keramik terjadi pada beberapa ruang pamer maupun tempat produksi sehingga aktivitasnya menyebar pada kawasan keramik Dinoyo.

\section{KESIMPULAN}

Keterbatasan fasilitas yang dimiliki oleh para pengrajin, yakni fasilitas ruang transisi bagi pengunjung saat berkunjung ke ruang pamer ataupun ruang produksi menimbulkan suasana kurang menerima kehadiran pengunjung, sehingga akan menurunkan citra pengrajin dalam pelayanan pengunjung. Setelah memasuki ruang aktivitas para pengrajin, terjadi pula suasana ruang yang kurang tertata dengan baik sehingga kenyamanan pengunjung dalam mengamati maupun memilih benda, serta sirkulasi ruang menjadi terkendala oleh barang-barang yang seharusnya dapat disimpan di gudang. Dalam lingkup yang lebih luas, akan didapatkan fasilitas antar tempat beraktivitas para pengrajin yang kurang nyaman karena tidak tersedianya teritori untuk pejalan kaki sebagai fasilitas penghubung antar tempat beraktivitas para pengrajin; maupun terbatasnya ruang penerima bagi pengunjung di kawasan, padahal terdapat aset properti yang belum difungsikan sesuai tuntutan kebutuhannya. Berdasarkan hal tersebut, maka dirasakan perlu untuk meningkatkan vitalitas kawasan dengan suasana menjadi lebih nyaman dalam membentuk citra kawasan kampung wisata keramik, serta merubah tempat yang belum difungsikan sesuai kebutuhan.

Kecenderungan pembongkaran dan penggusuran bangunan kuno yang bersejarah dan sebagai pembentuk budaya masyarakat setempat pada keterampilan pembuatan keramik yang sudah dikenal dunia perlu dicegah sedini mungkin. Revitalisasi dan pembangunan, bukanlah dikotomi guna dipilih salah satu melainkan merupakan dua muka dalam keping uang yang sama. Proses revitalisasi kawasan pengrajin keramik Dinoyo,

PAWON: Jurnal Arsitektur, Nomor 01 Volume 3, Bulan Januari-Juni Tahun 2019, ISSN 2597-7636 
diperlukan untuk meningkatkan pemanfaatan lingkungan karena potensi tata nilai sosial masyarakat, nilai ilmiah serta nilai komersial yang sudah memberikan identitas, pribadi maupun jati diri dan belum tergantikan hingga saat kini.

Kelebihan temuan dari penelitian ini adalah mengurangi permasalahan aksesibilitas pada kawasan pengrajin keramik Dinoyo, menambah kenyamanan bagi pengunjung untuk pemenuhan aktivitas belanja maupun wisata, meningkatkan karakteristik citra kawasan pengrajin keramik; meskipun memiliki kelemahan pada aksesibilitas pengunjung di kawasan maupun pada lokasi aktivitas pengrajin apabila jumlah pengunjung melebihi kapasitas tampung pada lokasi yang tersedia, keberadaan teritori pejalan kaki untuk mencapai aktivitas pengrajin dengan lebar yang terbatas sesuai potensi yang ada di kawasan, adanya peralihan fungsi ruang dari ruang komersial menjadi ruang transisi pada lahan pengrajin akan memberatkan secara ekonomi bagi yang memiliki lahan terbatas.

Konsep perancangan suatu kawasan, perlu mengacu pada enam hal yakni : aksesibilitas yakni keberadaan fasilitas untuk mengakses suatu tempat atau kawasan bagi para pemilik, pekerja maupun pengunjung dalam melakukan aktivitasnya menuju maupun meninggalkan suatu tempat dalam kawasan pengrajin keramik, kompatibilitas yakni memadukan aktivitas dari kegiatan spesifik dari suatu tempat atau kawasan pengrajin keramik maupun gips dengan fasilitas lain yang berupa tempat maupun lingkungan ataupun kawasan disebelahnya secara serasi sehingga dapat menghasilkan suasana interaksi yang nyaman dan menarik, baik bagi penghuni maupun pengunjung kawasan pengrajin, orientasi yakni merupakan suatu arah hadap bagi bangunan yang berada pada kawasan pengrajin dan hal tersebut dimaksudkan untuk memaknai karakteristik sesuai potensi dan permasalahan kawasan agar didapatkan produk rancangan yang spesifik sesuai keberadaan eksisting tapak, identitas yakni keberadaan suatu tapak secara geografis memiliki karakter sesuai budaya maupun potensi lingkungan kawasan serta menyelesaikan permasalahan suatu kawasan agar memiliki identitas sesuai sosial dan budaya juga memenuhi azas manfaat untuk memajukan ilmu pengetahuan bagi masyarakat yang berinteraksi dengan kawasan disini, ketertarikan akan menjadi sesuatu yang saling membutuhkan diantara pengrajin dan pengunjung sehingga masingmasing pihak berusaha melakukan interaksi dimana pihak pengrajin menyediakan pilihan produk kerajinan yang menarik minat pengunjung demikian pula kawasannya menjadi sesuatu yang menarik karena menumbuhkan keakraban dalam berinteraksi, kenyamanan karena didapatkannya fasilitas sesuai tuntutan kegiatan baik suasana lingkungan maupun proses berinteraksi antara pengrajin, pemilik maupun pengunjung dapat melakukan aktivitasnya dengan bebas dan tanpa tekanan pengaruh fisik atau psikis dalam pemenuhan kebutuhannya.

PAWON: Jurnal Arsitektur, Nomor 01 Volume 3, Bulan Januari-Juni Tahun 2019, ISSN 2597-7636 


\section{DAFTAR PUSTAKA}

Basrowi, Suwandi, 2008. Memahami Penelitian Kualitatif. Jakarta: Rineka Cipta.

Haryadi, Setiawan B, 2010. Arsitektur dan Perilaku. Yogyakarta: Gajah Mada University Press.

Joyce, Marcella Laurens, 2004. Arsitektur dan Perilaku Manusia. Jakarta: P.T. Grasindo.

Keating, 1994. Bumi Lestari Menuju Abad 21. Jakarta: Konphalindo.

Sidharta, Eko, 1989. Konservasi dan Bangunan Kuno Bersejarah Di Surakarta. Yogyakarta: Gajah Mada University Press.

Stokols, Daniel, 1977. Prespectives on Environment and Behavior: Theory, Research and Applications. New York: Plenum Press. 